\title{
PELATIHAN PENGOLAHAN SAMPAH DALAM MENINGKATKATKAN LIFE SKILL PADA KOMUNITAS PEDAGANG RUJAK BUAH DI KLENDER JAKARTA TIMUR
}

\author{
Karta Sasmita \\ Universitas Negeri Jakarta \\ Email: kartasasmita@gmail.com
}

\begin{abstract}
This study aimed to provide knowledge and understanding through training waste management in improving life skill on a community traders rujak fruit in rt.013 / rw.003. klender urban villageOn this research obtained a problem that community traders rujak fruit in rt $013 \mathrm{rw} 03$ klender do not have life skills how to process rubbish. So that efforts are required training in form of waste management to improve life skill on a community rujak traders such fruit. Of the study drawn the conclusion that traders make fruit have life skill in handling garbage to dump, and a lot of garbage and produced in RT 013 RW 003, thus, and will cause problems related to. garbageAs for the result of training on liquid compost and komposter products used by participants for restoration.
\end{abstract}

Keywords: training, life skill, garbage, liquid compost, komposter

\begin{abstract}
Abstrak
Penelitian ini bertujuan untuk memberikan pengetahuan dan pemahaman melalui Pelatihan pengolahan sampah dalam meningkatkan life skill pada komunitas pedagang rujak buah di RT.013/RW.003 Kelurahan Klender. Pada penelitian ini diperoleh masalah bahwa komunitas pedagang rujak buah di RT 013 RW 03 Klender belum memiliki life skill bagaimana cara mengolah sampah. Sehingga diperlukan upaya berupa pelatihan pengolahan sampah untuk dapat meningkatkan life skill pada komunitas pedagang rujak buah tersebut. Dari penelitian ditarik kesimpulan bahwa pedagang rujak buah mempunyai life skill pengolahan sampah untuk menangani masalah sampah, sehingga tidak banyak sampah lagi yang diproduksi di lingkungan RT 013 RW 003, dengan demikian, maka tidak akan timbul permasalahan yang berkaitan dengan sampah. Adapun hasil pelatihan berupa produk kompos cair dan komposter yang dipakai oleh peserta untuk penghijauan.
\end{abstract}

Kata Kunci : pelatihan, life skill, sampah, kompos cair, komposter

\section{PENDAHULUAN}

\section{A. Latar Belakang}

RT 013 RW 003 yang terdapat di Kelurahan Klender, merupakan wilayah dengan tingkat kepadatan penduduk yang cukup tinggi. RW 03 ini terbagi atas $15 \mathrm{RT}$, dengan total jumlah $\mathrm{KK}$ 3672 jiwa yang menempati. Mengingat cukup luasnya lokasi sasaran, maka dalam penulisan penelitian ini, penulis akan melakukan penelitian di lingkungan RT.013/ RW.003 Klender khususnya pada komunitas pedagang rujak buah.

Masyarakat RT.013 sebagian besar banyak yang bekerja sebagai pedagang rujak buah keliling. Menurut informasi ketua RT 013 sehari pedagang rujak 
buah keliling bisa menghasilkan dagangan rujak buahnya kira-kira 1 ton sampai 2 ton untuk dijual, hal ini menyebabkan banyaknya sampahsampah industri yang dihasilkan, seperti sampah dari kulit buah-buahan yang setiap hari menumpuk. Dalam satu hari sampah yang dibuang ke pembuangan sampah mencapai 2 sampai 3 gerobak dalam sehari, dan dalam sebulan sampah yang bisa diangkut truk sampah mencapai 2 sampai 3 truk.

Melihat kondisi lingkungan RT 013 ini sangat disayangkan, dalam keadaan seperti ini kepedulian terhadap pengolahan sampah dan lingkungannya sangatlah minim. Usaha yang telah dilakukan antara lain, oleh pedagang rujak buah serta masyarakat RT 013 dan Pemerintah Daerah setempat dalam rangka menanggulangi masalah sampah diatas antara lain, diadakannya program kerja bakti setiap 2 minggu sekali, dan Pemerintah daerah memberikan pengadaan sejumlah perangkat penunjang kebersihan seperti sapu, tempat/ bak sampah serta alat untuk mengolah sampah yaitu komposter, dan penanaman tumbuhan atau penghijauan.

Tidak adanya life skill, membuat pedagang rujak buah di RT 013 tidak bisa mengelola sampahnya dengan baik. Fenomena-fenomena yang terjadi ini adalah suatu permasalahan yang dapat menjadi sumber dari penurunaan atau memburuknya kualitas hidup masyarakat. Peranan Pendidikan Luar Sekolah dalam program pemberdayaan masyarakat yaitu ingin menciptakan manusia yang diharapkan nantinya dapat berdaya guna, dengan cara memberikan life skill (keterampilan hidup) yang nantinya setelah memiliki keterampilan diharapkan dapat mengatasi masalah dan kebutuhan hidupnya.

Peran Pendidikan Luar Sekolah dalam pemberdayaan masyarakat dalam menangani masalah yang telah dipaparkan diatas, yaitu ingin menciptakan manusia yang diharapkan nantinya dapat berdaya guna, dengan cara memberikan life skill (keterampilan hidup) yang nantinya setelah memiliki keterampilan masyarakat diharapkan dapat memenuhi kebutuhan hidupnya sehari-hari, selain itu peran Pendidikan Luar Sekolah yang sangat penting yaitu, untuk mensosialisasikan pengelolaan sampah bagi masyarakat, dengan cara mencari model aksi Pendidikan Luar Sekolah untuk mengembangkan strategi atas masalah tersebut dan memberikan 
suatu mekanisme alternatif seperti pengelolaan sampah serta pelatihan pembuatan kompos cair sebagaimana untuk meningkatkan life skill.

Berdasarkan hal tersebut, maka pokok penelitian ini adalah sebagai berikut: "pelatihan pengolahan sampah dalam meningkatkan life skill pada komunitas pedagang rujak buah".

\section{B. Identifikasi Masalah}

Dari latar belakang masalah yang penulis telah paparkan di atas, maka penulis mengidentifikasi beberapa permasalahan sebagai berikut:

1. Bagaimana aktivitas ekonomi masyarakat RT.013/RW.003

Kelurahan Klender, Duren Sawit, Jakarta Timur?

2. Apa saja sampah yang dihasilkan pedagang rujak buah RT.013/RW.003 Kelurahan Klender, Duren Sawit, Jakarta Timur?

3. Bagaimana kesadaran dan pengetahuan komunitas pedagang rujak buah RT 013/RW003 mengenai pengelolaan sampah?

4. Bagaimana komunitas pedagang rujak buah RT.013/RW.003 mengatasi limbah sampah basah tersebut?
5. Bagaimana cara penerapan pelatihan pengolahan sampah dalam meningkatkan life skill pada komunitas pedagang rujak buah di RT.013/RW.003?

6. Apakah penerapan pelatihan pengolahan sampah dapat meningkatkan life skill pada komunitas pedagang rujak buah?

\section{Pembatasan Masalah}

Berdasarkan latar belakang masalah dan identifikasi masalah, penulis membatasi permasalahan dengan berfokus pada pelatihan pengolahan sampah dalam meningkatkan life skill komunitas pedagang rujak buah yang terdapat di RT.013/RW.003 Kelurahan Klender, Kecamatan Duren Sawit, Jakarta Timur, DKI Jakarta.

\section{Perumusan Masalah}

Mengacu pada latar belakang masalah, identifikasi masalah dan pembatasan masalah, maka penulis merumuskan permasalahan sebagai berikut: "apakah melalui pelatihan pengolahan sampah dapat meningkatkan life skill komunitas pedagang rujak buah yang terdapat di RT.013/RW003 Kelurahan Klender, 
Kecamatan Duren Sawit, Jakarta Timur, DKI Jakarta?"

\section{KERANGKA TEORITIS}

\section{A. Kajian Teori}

\section{Hakikat Pelatihan}

\section{a. Pengertian Pelatihan}

Moekijat dalam buku Anwar mengemukakan bahwa: Pelatihan adalah sutau kegiatan penyesuaian atau pemberian pengaruh kepada seseorang pegawai untuk meningkatkan kecakapannya guna suatu kegiatan tertentu. Arti sepenuhnya lebih banyak memberikan pengetahuan, karena pelatihan mencakup baik pengalaman mengerjakan suatu pekerjaan maupun pengatahuan.

Ada juga menurut Faustino Cardoso Gomes dalam bukunya Manajemen Sumber Daya Manusia yang mengatakan bahwa :

"Pelatihan adalah setiap usaha untuk memperbaiki kualitas kerja pada suatu pekerjaan tertentu yang sedang menjadi tanggung jawabnya, atau suatu pekerjaan yang ada kaitannya dengan pekerjaannya. Idealnya pelatihan harus didesain untuk mewujudkan tujuantujuan organisasi, perusahaan, lembaga ataupun instansi yang ada pada waktu bersamaan juga, mewujudkan tujuantujuan dari para pekerja secara perorangan".

Dari bebagai pendapat para ahli diatas dapat disimpulkan bahwa pelatihan merupakan serangkaian upaya yang dilaksanakan dengan sengaja dalam bentuk pemberian bantuan kepada seseorang/kelompok untuk meningkatkan berbagai pengetahuan yaitu pengetahuan berupa kecakapan dan keterampilan bagi seseorang/kelompok untuk memberikan kemungkinan perubahan yang dilandasi motivasi untuk berprestasi dalam menghasilkan kualitas kerja pada pekerjaan tertentu.

\section{b. Tujuan Pelatihan}

Dalam mengadakan program pelatihan bagi suatu organisasi pasti tidak mengadakan kegiatan begitu saja, akan tetapi harus mampu memahami dan mengetahui lebih jauh atas program yang akan dijalankannya, seperti halnya kepada siapa program itu akan diberikan, apakah program yang dijalankan dapat bermanfaat kedua belah pihak (peserta dan pengajar), pentingkah program itu diadakan.

Menurut Sudjana yang dikutip oleh Moenir dalam buku kepemimpinan kerja mengungkapkan bahwa pelatihan 
merupakaan suatu proses yang dinamis untuk mencapai tujuan tertentu. Keberhasilan tersebut dapat dilihat dari dua segi, yaitu:

1) Segi proses

Kriteria keberhasilan pelatihan dilihat dari sudut proses lebih menekankan kepada pengajaran sebagai suatu proses haruslah merupakan interaksi dinamis sehingga sebagai subjek yang belajar mampu mengembangkan potensinya melalui belajar sendiri, dan tujuan yang telah ditetapkan tercapai secara efektif.

2) Segi hasil

Kriteria keberhasilan pelatihan dilihat dari segi hasil lebih menekankan pada tinglkat penguasaan tujuan oleh siswa baik dari segi kualitas maupun kuantitas.

Adapun tujuan dari pelatihan pengolahan sampah yaitu untuk memberikan pemahaman dan keterampilan kepada komunitas pedagang rujak buah keliling untuk mengatasi dan mengolah masalah limbah sampah mereka menjadi nilai yang berdaya guna sekalgus mengurangi pencemaran lingkungan di lingkungan tempat tinggal mereka.

\section{c. Manfaat Pelatihan}

Pelatihan juga memiliki sejumlah manfaat, seperti yang dikemukakan Siagian bahwa ada 10 manfaat yang dapat dipetik oleh pegawai atau karyawan dari kegiatan pelatihan sebagai berikut:

1) Membantu pegawai membuat keputusan yang lebih baik,

2) Meningkatkan kemampuan para pekerja menyelesaikan berbagai masalah yang dihadapinya,

3) Terjadinya interaksi dan operasionalisasi faktor-faktor motivasional,

4) Timbulnya dorongan dalam diri pekerja untuk terus meningkatkan kemampuan kerjanya,

5) Peningkatan kemampuan pegawai untuk mengatasi; stress, frustasi, dan konflik yang ada pada gilirannya memperbesar rasa percaya diri sendiri,

6) Tersedianya informasi berbagai program yang dapat dimaanfaatkan para pegawai dalam rangka pertumbuhan secara teknikal dan intelektual,

7) Meningkatkan kepuasan kerja,

8) Semakin besar pengakuan atas kemampuan seseorang, 
9) Makin besarnya tekad pekerja untuk lebih mandiri,

10) Mengurangi ketakutan menghadapi tugas-tugas baru di masa depan.

Adapun manfaat pelatihan pengolahan sampah yaitu membantu komunitas pedagang rujak buah memanfaatkan sampah hasil industri mereka menjadi barang bernilai guna dengan mengolah sampah limbah industri tersebut.

\section{d. Komponen Pelatihan}

Pelatihan adalah sebuah kegiatan yang harus direncanakan terlebih dahulu untuk mencapai tujuan yang sudah kita tetapkan. Oleh sebab itu, demi mencapai tujuan tersebut serta pada prosesnya berjalan dengan lancar, maka terdapat komponen-komponen pelatihan yang harus diperhatikan.

Menurut A.A Prabu dalam bukunya Manajemen Sumber Daya Manusia Perusahaan komponen-komponen pelatihan dan pengembangannya yaitu:

1) Tujuan dan sasaran pelatihan dan pengambngan harus jelas dan dapat diukur,

2) Para pelatih harus memiliki kualifikasi yang memadai,
3) Materi pelatihan dan pengembangan harus disesuaikan dengan yang hendak dicapai,

4) Metode pelatihan dan pengambangan harus sesuai dengan tingkat kemampuan pegawai yang menjadi peserta,

5) Peserta pelatihan dan pengembangan harus memenuhi persyaratan yang ditentukan.

Dari uraian diatas, maka untuk mencapai hasil pelatihan yang maksimal maka harus ada suatu tujuan yang jelas dalam melaksanakan sebuah pelatihan. Selanjutnya pelatih yang digunakan untuk memberi pelatihan kepada para peserta pelatihan pun harus mempunyai kualifikasi yang bagus. Materi pelatihan yang dibuatpun harus benar-benar sesuai dengan konteks pelatihan yang dilakukan.

\section{e. Pelatihan Pengolahan Sampah}

Pengertian pelatihan menurut peneliti yang telah disimpulkan diatas bahwa pelatihan merupakan serangkaian upaya yang dilaksanakan dengan sengaja dalam bentuk pemberian bantuan kepada seseorang/ kelompok untuk meningkatkan berbagai pengetahuan yaitu pengetahuan berupa kecakapan dan keterampilan bagi seseorang/ kelompok 
untuk memberikan kemungkinan perubahan yang dilandasi motivasi untuk berprestasi dalam menghasilkan kualitas kerja pada pekerjaan tertentu.

Menurut peneliti pengertian pelatihan pengolahan sampah yaitu serangkaian upaya kegiatan dalam bentuk pemberian bantuan kepada seseorang/ kelompok untuk meningkatkan berbagai pengetahuan pengolahan berupa sampah zat padat, zat cair, gas, atau radio aktif dengan metode dan keahlian khusus yang dilaksanakan dengan sengaja.

Pelatihan pengolahan sampah yang dilaksanakan oleh peneliti terhadap komunitas pedagang rujak buah yang terdapat di RT 013 RW 003 Kelurahan Klender yaitu dengan memberikan pelatihan pengolahan sampah menjadi kompos cair. Pelatihan ini dimaksudkan untuk meningkatkan life skill masyarakat dan menggali potensi sumber daya yang terdapat di wilayah RT 013 RW 003 Kelurahan Klender.

\section{Hakikat Sampah}

\section{a. Pengertian Sampah}

Menurut kamus istilah lingkungan yang dikutip oleh Alex S Sampah adalah bahan yang tidak mempunyai nilai atau tidak berharga untuk maksud biasa atau utama dalam pembikinan atau pemakaian barang rusak atau bercacat dalam pembikinan manufaktur atau materi berkelebihan atau ditolak atau buangan.

Kemudian menurut Ecolink yang dikutip oleh Alex S Sampah adalah suatu bahan yang terbuang atau dibuang dari sumber hasil aktivitas manusia maupun proses alam yang belum memiliki nilai ekonomis.

Apabila bahan-bahan tersebut berada didaratan atau perairan dalam waktu yang lama akan menimbulkan gangguan terhadap kehidupan manusia, hewan maupun tanaman maka jika itu terjadi dapat dikatakan daratan maupun perairan telah tercemar.

Kesimpulan pengertian sampah menurut peneliti adalah barang yang sudah tidak dipakai atau barang sisa dari aktifitas manusia sehari-hari, sampah erat kaitannya dengan kesehatan manusia, oleh sebab itu sampah harus dikelola dengan baik sampahi sekecil mungkin tidak menggangu atau mengancam kesehatan manusia. Pengelolahan sampah yang baik bukan saja untuk kepentingan kesehatan saja, tetapi juga untuk keindahan.

\section{b. Jenis-Jenis Sampah}


Berdasarkan hal tersebut sampah menurut jenisnya digolongkan menjadi:

\section{Sampah Organik}

Pada umumnya sampah organik adalah sampah yang dapat membusuk atau terdegradasai oleh mikroorganisme dan akan lebih bijaksana jika limbah buangan organik tidak dibuang ke dalam air. Karena, dapat menaikan mikroorganisme di dalam air. Bahan buang organik sebaiknya dikumpulkan untuk diproses menjadi pupuk kompos yang berguna bagi tanaman, dengan melakukan pengomposan berarti mendaur ulang limbah dan tentu saja akan berdampak positif bagi lingkungan serta kehidupan.

\section{Sampah Nonorganik}

Pada umumnya sampah nonorganik berupa sampah yang tidak dapat membusuk dan sulit untuk didegradasi oleh mikroorganisme, apabila bahan buang ini masuk ke dalam air atau lingkungan maka akan terjadi peningkatan jumlah ion logam di dalam air. Bahan buangan nonorganik biasanya berasal dari industri yang melibatkan unsur-unsur logam.
Berdasarkan bentuknya sampah dapat dibagi sebagai:

1. Sampah Padat

Sampah padat adalah segala bahan buangan selain kotoran manusia, urin dan sampah cair. Dapat berupa sampah rumah tangga: sampah dapur, sampah kebun, plastik, metal, gelas dan lain-lain. Menurut bahannya sampah ini dikelompokkan menjadi sampah organik dan sampah anorganik. Sampah organik Merupakan sampah yang berasal dari barang yang mengandung bahanbahan organik, seperti sisa-sisa sayuran, hewan, kertas, potonganpotongan kayu dari peralatan rumah tangga, potongan-potongan ranting, rumput pada waktu pembersihan kebun dan sebagainya.

Berdasarkan kemampuan diurai oleh alam (biodegradability), maka dapat dibagi lagi menjadi:

a. Biodegradable: yaitu sampah yang dapat diuraikan secara sempurna oleh proses biologi baik aerob atau anaerob, seperti: sampah dapur, sisasisa hewan, sampah pertanian dan perkebunan.

b. Non-biodegradable: yaitu sampah yang tidak bisa diuraikan oleh 
proses biologi. Dapat dibagi lagi menjadi 2 yaitu Recyclable adalah sampah yang dapat diolah dan digunakan kembali karena memiliki nilai secara ekonomi seperti plastik, kertas, pakaian dan lain-lain dan Nonrecyclable adalah sampah yang tidak memiliki nilai ekonomi dan tidak dapat diolah atau diubah kembali seperti tetra packs, carbon paper, thermo coal dan lain-lain.

\section{Sampah Cair}

Sampah cair adalah bahan cairan yang telah digunakan dan tidak diperlukan kembali dan dibuang ke tempat pembuangan sampah. Sapah cair dapat dibagi lagi menjadi 2 tipe sampah, yaitu:

a) Limbah hitam: sampah cair yang dihasilkan dari toilet. Sampah ini mengandung patogen yang berbahaya.

b) Limbah rumah tangga: sampah cair yang dihasilkan dari dapur, kamar mandi dan tempat cucian. Sampah ini mungkin mengandung patogen.

Jenis-jenis sampah yang telah dipaparkan diatas, sampah yang peneliti akan olah menjadi pupuk kompos cair adalah sampah organik. Warga RT 013 RW 003 banyak berprofesi menjadi pedagang rujak buah keliling, sampah yang dihasilkan dari pedagang rujak tersebut berupa sampah organik, sampah dari kulit buah-buahan selain itu juga banyak sampah rumah tangga. Sampah organik tersebut bisa menjadi barang yang bernilai guna jika dikelola dengan pengelolaan sampah yang baik menjadi pupuk kompos cair. Peneliti memilih jenis sampah organik yaitu sampah dari kulit buah-buahan untuk dikelola dengan pengelolaan sampah menjadi pupuk kompos cair.

\section{c. Daur Ulang}

Daur ulang adalah sesuatu yang luar biasa yang bisa didapatkan dari sampah. Proses daur ulang alumunium dapat menghemat $95 \%$ energi dan mengurangi polusi udara sebanyak $95 \%$ jika dibandingkan dengan ekstraksi alumunium dari tambang hingga prosesnya di pabrik. Penghematan yang cukup besar pada energi juga didapat dengan mendaur ulang kertas, logam, kaca, dan plastik.

Kesimpulan daur ulang menurut peneliti adalah meminimalisasikan sampah yang terus dihasilkan oleh komunitas pedagang rujak buah RT 013 RW 003, dimana sampah yang telah dipilah dapat dimanfaatkan, diproses 
ulang dan dibuat menjadi barang yang bernilai guna.

\section{Hakikat Life skill}

\section{a. Pengertian Life skill}

Pendidikan Kecakapan Hidup (life skills) lebih luas dari sekedar keterampilan bekerja, apalagi sekedar keterampilan manual. Pendidikan kecakapan hidup merupakan konsep pendidikan yang bertujuan untuk mempersiapkan warga belajar agar memiliki keberanian dan kemauan menghadapi masalah hidup dan kehidupan secara wajar tanpa merasa tertekan kemudian secara kreatif menemukan solusi serta mampu mengatasinya.

Pada intinya menurut peneliti pendidikan life skill adalah pendidikan yang memberikan modal dan bekal dasar yang dilakukan secara benar kepada peserta didik tentang nilai-nilai kehidupan yang dibutuhkan dan berguna bagi perkembangan kehidupan peserta didik. Dengan demikian pendidikan life skill harus dapat merefleksikan kehidupan nyata dalam proses pengajaran agar peserta didik memperoleh kecakapan hidup tersebut, sehingga berguna bagi kehidupan peserta didik.

\section{b. Tujuan Life skill}

Menurut Achmad Taufik, pada intinya, pendidikan life skill ditujukan untuk perkembangan pendidikan yang semakin baik di masa mendatang. Garis besar tujuan pendidikan life skill sebagai berikut:

a. Mengaktualisasikan potensi peserta didik sehingga dapat memecahkan permasalahan yang dihadapi

b. Memberikan kesempatan kepada sekolah untuk mengembangkan pembelajaran yang fleksibel, sesuai dengan prinsip pendidikan berbasis luas

c. Pemanfaatan sumber daya di lingkungan sekolah, dengan memberi peluang pemanfaatan sumber daya yang ada di masyarakat, sesuai dengan prinsip manajemen berbasis sekolah

d. Mengembangkan potensi manusiawi peserta didik menghadapi perannya dimasa mendatang

e. Membebankan pembelajaran yang fleksibel dan memanfaatkan potensi SDM yang ada di masyarakat dengan prinsip Manajemen Berbasis Sekolah 
f. Membekali peserta didik dengan kecakapan hidup sebagai pribadi yang mandiri.

Adapun tujuan Life skill pelatihan pengelohan sampah yang peneli akan laksanakan, yaitu untuk meningkatkan keterampilan, pengetahuan, dan sikap warga RT 013 RW 003 khususnya pada komunitas pedagang rujak buah supaya mereka memiliki bekal kemampuan untuk meningkatkan kualitas hidupnya dan bisa mengatasi masalah sampah hasil industri mereka dengan mengelola sampah menjadi pupuk kompos cair.

\section{c. Manfaat Life Skill}

Menurut Achmad Taufik dengan adanya pendidikan kecakapan hidup (Life Skill) bagi masyarakat ini akan memberikan manfaat yang nyata baik secara pribadi peserta didik maupun terhadap masyarakat lainnya yaitu:

1) Bagi peserta didik, akan dapat meningkatkan kualitas berfikir, kualitas kalbu, dan kualitas fisik. Peningkatan kualitas tersebut pada gilirannya akan dapat meningkatkan pilihan -pilihan dalam kehidupan individu, misalnya karir, penghasilan, pengaruh, prestise, kesehatan jasmani dan rohani, peluang pengembangan diri, kemampuan kompetitif dan kesejahteraan pribadi.

2) Bagi masyarakat, dapat meningkatkan kehidupan yang maju dan madani dengan indikator-indikator sebagai berikut: peningkatan kesejahteraan sosial, pengurangan prilaku destruktif sehingga dapat mereduksi masalahmasalah sosial dan tumbuhnya harmonisasi dalam masyarakat dengan memadukan nilai-nilai religi, solidaritas, ekonomi, kuasa dan seni (cita rasa).

Melihat dari pendapat tersebut, maka dalam pelatihan ini manfaat dari meningkatnya life skill para pedagang rujak buah tersebut yaitu dapat meningkatknya kualitas kehidupan menjadi lebih baik lagi dengan meningkatknya pengetahuan dan pemahaman para pedagang rujak buah mengenai mengolah sampah yang di hasilkan dari industri mereka tersebut, sehingaa bisa menjadi barang yang berdaya nilai guna.

\section{B. Kerangka Berfikir}

Peneliti memilih komunitas pedagang rujak buah di wilayah RT 013 RW 003 Kelurahan Klender sebagai objek penelitian, karena tingkat pengetahuan, pemahaman dan keterampilan yang 
masih rendah tentang pengolahan sampah, selain itu kepedulian terhadap pengolahan sampah dan lingkungannya sangatlah minim.

Adapun tujuan dari pelatihan yang peneliti lakukan terhadap pedagang rujak buah dengan memberikan pelatihan pengolahan sampah menjadi kompos cair yaitu lebih kepada untuk meningkatkan pengetahuan dan pemahaman terhadap pengelolaan sampah dan juga untuk meningkatkan life skill para pedagang rujak buah tersebut.

Setelah meningkatknya life skill para pedagang rujak buah, maka diharapkan mereka bisa mengelola sampah dan mengurangi volume sampah dari industri mereka tersebut. Bila mereka mengelola sampah di lingkugan mereka dengan baik, tidak menutup kemungkinan lingkungan tempat tinggal mereka juga menjadi bersih dan terbebas dari sampah yang artinya mereka melakukan upaya mencegah pencemaran lingkungan.

\section{Hipotesis}

Hipotesis adalah rumusan jawaban atau kesimpulan pada penelitian ini. Untuk itu dalam penelitian ini saya sebagai penulis mempunyai hipotesis yaitu, dengan di berikannya pelatihan pengolahan sampah dapat meningkatkan life skill komunitas pedagang rujak buah di RT.013/RW.003 Kelurahan Klender, Kecamatan Duren Sawit, Jakarta Timur.

\section{METODOLOGI PENELITIAN}

\section{A. Tujuan Penelitian}

Tujuan dari penelitian ini adalah untuk memberikan gambaran lebih kepada untuk meningkatkan pengetahuan dan pemahaman mengenai program pelatihan pengolahan sampah dalam meningkatkan life skill komunitas pedagang rujak buah, di RT 013 RW 003 kelurahan Klender, Jakarta Timur, selain itu penelitian ini juga sebagai upaya dalam pencegahan pencemaran lingkungan.

\section{B. Tempat dan Waktu Penelitian}

Penelitian ini bertempat di wilayah lingkungan sekitar RT 013 RW 003 kelurahan Klender, Jakarta Timur. Waktu penelitian terhitung dari bulan agustus 2012 sampai desember 2012, dengan perincian waktu meliputi dua bulan untuk persiapan, dimana persiapan tersebut berisikan kegiatan identifikasi awal, pengumpulan data yang berkaitan dengan permasalahan, serta tiga bulan selanjutnya pelaksanaan penelitian.

\section{Metode Penelitian dan Desain Penelitian}


Penelitian yang digunakan merupakan penelitian eksperimen semu dengan desain penelitian one group pre test and post test design. Penelitian ini menggunakan desain rancangan penelitian pre tes dan post test pada satu kelompok. Hal yang pertama dilakukan adalah pengukuran pre test untuk melihat kondisi pencapaian sikap lalu dikenakan perlakuan (treatment) program pelatihan pengolahan sampah. Selanjutnya, dilakukan pengukuran kedua (post test) untuk melihat kondisi akhir subjek penelitian.

\section{Populasi Dan Teknik}

\section{Pengambilan Sampel}

Populasi dalam penelitian ini adalah komunitas pedagang rujak buah yang berjumlah 25 yang berada di RT 013 RW 003 Kelurahan Klender Jakarta Timur. Jumlah tersebut berdasarkan data di lapangan yang peneliti dapatkan.

Sampel dalam penelitian ini ditentukan dengan menggunakan teknik purposive sampling. Teknik sampling ini diberi nama demikian karena di dalam pengambilan sampelnya, peneliti "mencampur" subjek-subjek di dalam populasi sehingga semua subyek dianggap sama. Adapun jumlah sampel yang diteliti dalam penelitian ini yakni sebanyak 15 orang.

\section{HASIL PENELITIAN}

\section{A. Pembahasan}

Setelah pengujian hipotesis dilakukan, hasilnya menyatakan bahwa menolak Ho dan menerima $\mathrm{Hi}$, yang menyatakan bahwa terdapat peningkatan life skill pada pedagang rujak buah untuk mengatasi limbah industrinya melalui pelatihan pengolahan sampah. Pelatihan pengolahan sampah dilaksanakan sebagai salah satu upaya atau solusi dari permasalahan sampah kulit buahbuahan dari pedagang rujak buah sampah Penerapannya, pelatihan pengolahan sampah ini tidak lepas dari variabel-variabel penelitian seperti materi, metode, fasilitator, media, dan yang terpenting adalah peserta, karena tanpa adanya peserta mustahil dijalankan sebuah proses pelatihan.

Hasil pelatihan ini juga dilakukan melalui tes hasil yaitu pre test dan post test terhadap peserta pelatihan, dimana diperoleh nilai uji pengetahuan dan pemahaman pada pre test 15 orang responden dari 25 item soal yang diujikan memperoleh nilai rata-rata 5,04 dan post tes memperoleh nilai rata-rata 
8,16. Mengalami kenaikan nilai rata-rata sebesar 3,097 sesudah peserta pelatihan diberikan treatment pelatihan pengolahan sampah dalam meningkatkan life skill pada komunitas pedagang rujak buah.

Berdasarkan hasil nilai rata-rata penilaian soal sebelum dan sesudah diberikan treatment terdapat pengaruh yang signifikan, hal ini dapat disimpulkan bahwa dari pelatihan ini pedagang rujak buah akhirnya mempunyai life skill pengolahan sampah untuk menangani masalah sampah mereka. Banyakan peserta mampu memahami bagaimana mengelola sampah dan menjaga lingkungan, sehingga tidak banyak sampah lagi yang diproduksi di lingkungan sekitar tempat tinggal pedagang rujak buah dan masyarakat RT 013 RW 003, dengan demikian, maka tidak akan timbul berbagai permasalahan yang berkaitan dengan sampah di lingkungan. Adapun hasil pelatihan berupa produk kompos cair dan komposter yang dipakai oleh peserta untuk penghijauan.

\section{PENUTUP}

\section{A. Kesimpulan}

Berdasarkan data dari hasil penelitian dilapangan yang telah diperoleh peneliti mengenai "Pelatihan Pengolahan Sampah Dalam Meningkatkan Life Skill Pada Komunitas Pedagang Rujak Buah Di RT 013 RW 003 Kelurahan Klender”. Maka dapat disimpulkan beberapa poin sebagai berikut:

1. Dari proses identifikasi yang dilakukan peneliti ditemukan permasalahan Sampah yang dihasil pedagang rujak buah di lingkungan RT 013/RW 003 seharusnya bisa di kelola dengan baik dan bisa menghasilkan nilai guna yang tentu akan menambah penghasilan maupun lahan usaha, bagi masyarakat RT 013.

2. Sampah yang dihasilkan pedagang rujak buah adalah sampah industri, sampah buah-buahan yang tergolong sampah organik bila diolah dan diikelola dapat dijadikan pupuk kompos cair yang bernilai guna dan bernilai jual.

3. Tidak adanya life skill, membuat pedagang rujak buah di RT 013 tidak bisa mengelola sampahnya dengan baik.

4. Peranan Pendidikan Luar Sekolah dalam program pemberdayaan 
masyarakat yaitu ingin menciptakan manusia yang diharapkan nantinya dapat berdaya guna, dengan cara memberikan life skill (keterampilan hidup) yang nantinya setelah memiliki keterampilan diharapkan dapat mengatasi masalah dan kebutuhan hidupnya.

5. Dalam penelitian ini data yang di peroleh melalui multi instrumen, yaitu angket, observasi dan tes hasil belajar (pre test dan post test).

6. Setelah dilaksanakannya pelatihan dan mengolah data, peneliti mendapatkan hasil dari kegiatan pre test dan post test, maka dimana diperoleh nilai uji pengetahuan dan pemahaman pada pre test 15 orang responden dari 25 item soal yang diujikan memperoleh nilai rata-rata 5,04 dan post tes memperoleh nilai rata-rata 8,16 . Mengalami kenaikan nilai rata-rata sebesar 3,097 sesudah peserta pelatihan diberikan treatment pelatihan pengolahan sampah dalam meningkatkan life skill pada komunitas pedagang rujak buah.

\section{B. Saran}

Saran dari peneliti setelah mengetahui hasil penelitian sebgai berikut:
1. Bagi Peserta Pelatihan (pedagang rujak buah)

Setelah mengikuti pelatihan dan memiliki life skill yang di dapat dari proses pelatihan pengolahan sampah, diharapakan peserta pelatihan (pedagang rujak buah) mampu mengolah sampah yang dihasilkan dari industrinya.

2. Bagi ketua RT 013 dan Ketua RW 003

Agar membuat suatu kebijakan untuk menindaklanjuti hasil pelatihan pengolahan sampah dengan bersinergi antara masyarakat dan kelurahan klender.

\section{Bagi Jurusan PLS}

Mengingat pentingnya masalah yang dibahas dalam penelitian ini, maka perlu kiranya melakukan kaji aksi seperti ini pada wilayah dengan skala yang lebih luas.

4. Bagi Peneliti Lain

Dengan adanya penelitian ini diharapkan dapat menjadi referensii salah penyelesaian masalah sampah melalui pelatihan pengolahan sampah. Peneliti lain diharapkan dapat mengembangkan pelatihan pengolahan sampah yang lebih 
menarik dan efektif dalam menyelesaikan masalah sampah.

\section{DAFTAR PUSTAKA}

Blogspot.com/2012/03/pengertianpengolahan.html. diakses tanggal 23 oktober 2012.

Burhan, M. Bungin. 2005. Metode Penelitian Kuantitatif. Jakarta: Prenada Media.

Dainur. 1992. ilmu Kesehatan Masyarakat. Jakarta: Widya Medika.

Gomes, Faustino Cardoso. 1995. Manajemen Sumber Daya Manusia. Yogyakarta: Andi Offset.

Lynton, Ralph P. 1984. Pelatihan dan Pengembangan Tenaga Kerja. Jakarta: Pustaka Binaan Presindo.

Manulang, M. 1978. Pengembangan Pegawai. Medan: BKLM.

Moekijat. 1990. Latihan dan Pengembangan Sumber Daya Manusia. Bandung : CV. Mandar Maju.

Panggabean, Mutiara S. 2004. Manajemen Sumber Daya Manusia. Bogor: Ghalia Indonesia.
Prof. Dr. Arikunto, Suharsimi. 2002. Prosedur penelitian Suatu Pendekatan Praktek Edisi Revisi V. Jakarta: Rineka Cipta.

S. Alex. 2009. Sukses Mengolah Sampah Organik Menjadi Pupuk Organik. Yogyakarta: Pustaka Baru Press.

Siagian, Sondang P. 1998. Manajemen Sumber Daya Manusia. Jakarta : Bumi Aksara.

Sudirman. 2004. the complete bookof training. Bandung: ALFABETA. Sudjana, Nana dan Ibrahim. 1989. Penelitian dan Penelitian Pendidikan. Bandung: Sinar Baru.

Wardhana, Wisnu Arya. 2004. Dampak Pencemaran Lingkungan. Yogyakarta: Adhi Yogyakarta.

Wikipedia,http://id.wikipedia.org/wiki/

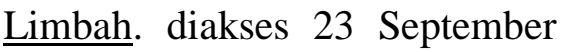
2012.

Wikipedia.org/wiki/pengelolaan_sampa h. diakses 23 oktober 2012.

Wingkel, WS. 1991. Psikologi Pengajaran. Jakarta: Grasindo.

Yunus, Dadang. Pengertian Pendidikan Kecakapan Hidup (Life Skills). http://pkbmpls.wordpress.com/2 008/02/06/pengertian- 
Jurnal Parameter Volume 30 No. 2 DOI : doi.org/10.21009/parameter.302.01

P-ISSN : 0216-261X E-ISSN : 2620-9519

pendidikan-kecakapan-hidup-

life-skills/. Diakses 23 oktober 2012.
Zuriah Nurul. 2006. Metodologi Penelitian Sosial dan

Pendidikan. Jakarta: Bumi

Aksara. 